\title{
Observations of nesting in the Papuan Flyrobin and the Olive Flyrobin, and post-fledging care in the Torrent Flycatcher, all endemic to New Guinea
}

\author{
Richard H. Donaghey \\ Environmental Futures Research Institute, Griffith University, Nathan 4111 QLD, Australia \\ Address for correspondence: 80 Sawards Road, Myalla TAS 7325, Australia \\ Email: ricardo@southernphone.com.au
}

\begin{abstract}
The nesting season, nest materials and dimensions, nest-site, and incubation and anti-predator behaviour of the Papuan Flyrobin Devioeca papuana, and nest and egg of the Olive Flyrobin Kempiella flavovirescens, both species endemic to New Guinea, are described. An observation of cooperative post-fledging care of two juvenile Torrent Flycatchers Monachella muelleriana is presented. Incubation feeding occurred in the Papuan Flyrobin and incubation constancy was $54 \%$. Papuan Flyrobin incubation behaviour, such as nest-attentiveness, frequency of nest visits and duration of on- and off-bouts, and nest failure are discussed and compared with those of the Jacky Winter Microeca fascinans, Lemon-bellied Flycatcher M. flavigaster and northern temperate passerines. Flyrobin nest failure and potential avian predators are discussed.
\end{abstract}

\section{Introduction}

Flyrobins are small, flycatcher-like, mostly arboreal, insectivorous Australasian robins (Petroicidae) occurring in Australia and on the islands of New Guinea, the Bismarck Archipelago, New Caledonia and Tanimbar (Boles 2007). The common name 'flyrobin' for species within the Microecinae is recognised by Boles (2007), Dutson (2011), Beehler \& Pratt (2016) and the International Ornithological Committee (Gill \& Donsker 2017), whereas 'flycatcher' was used by Christidis \& Boles (2008). Phylogenetic and DNA analyses by Christidis et al. (2011) identified six lineages or subfamilies within the Petroicidae and recognised eight species in five genera within the Microecinae. For the six New Guinean Microecinae species, Christidis et al. (2011) retained Monachella muelleriana for the Torrent Flycatcher and Microeca for the Jacky Winter (M. fascinans) and Lemon-bellied Flycatcher ( $M$. flavigaster). They placed the two sister species Microeca flavovirescens and M. griseoceps in the genus Kempiella and proposed the genus Devioeca for M. papuana, the most divergent, basal Microeca.

This paper follows IOC version 7.1 (Gill \& Donkser 2017) for avian family names but for New Guinean robins it follows the taxonomy and nomenclature of Beehler \& Pratt (2016), who recognised the generic changes of Christidis et al. (2011), and follows Christidis \& Boles (2008) in usage of the common name Lemon-bellied Flycatcher. Of the six species of New Guinean robins in the Microecinae, the Torrent Flycatcher inhabits streams and streamsides, the two Microeca species (which also occur in Australia), the Lemon-bellied Flycatcher and Jacky Winter, inhabit woodland, and the three rainforest species, segregated by elevation, are the lowland Olive Flyrobin Kempiella flavovirescens, the hillforest Yellow-legged Flyrobin K. griseoceps and the montane Papuan Flyrobin Devioeca papuana. These three rainforest New Guinean flyrobins are arboreal insectivores that capture prey mostly by hawking and some sally-snatching at foliage from perches at all levels from the understorey to the canopy but mostly in the lower or middle forest storey (Croxall 1977; Boles 2007). The Papuan Flyrobin (13.5-15 g: Diamond 1972) is endemic to New Guinea and is distributed throughout the Central Ranges and outlying Huon Peninsula, North Coastal Ranges, and Foja and Vogelkop mountains. It inhabits mid-higher montane forest mainly from $1800-2500 \mathrm{~m}$ to as low as $1100 \mathrm{~m}$ and as high as $3500 \mathrm{~m}$ above sea-level (asl) (Coates 1990; Boles 2007). The nest materials and dimensions, egg, clutch-size and parental care of the Papuan Flyrobin are undescribed (Coates 1990; Boles 2007). The Olive Flyrobin (13-17 g: Diamond 1972; Bell 1982a) is widespread throughout lowland New Guinea and its satellite islands (Coates 1990; Boles 2007; Pratt \& Beehler 2015) from sea-level to $1000 \mathrm{~m}$ asl (Beehler \& Pratt 2016) and is endemic to New Guinea. The nest dimensions and egg of the Olive Flyrobin are also undescribed (Rand \& Gilliard 1967; Coates 1990; Boles 2007). The Torrent Flycatcher (23-27.5 g; Diamond 1972) frequents fast-flowing streams from the foothills to $2100 \mathrm{~m}$ asl throughout the Central Ranges of New Guinea and outlying mountains of the North Coastal Ranges, Foja, Vogelkop and Huon Peninsula, and New Britain. Little is known about its breeding behaviour (Coates 1990; Boles 2007).

This paper describes the nesting season, nest materials and dimensions, nest-site, incubation behaviour and antipredator behaviour of the Papuan Flyrobin, and the nest materials and dimensions, and egg of the Olive Flyrobin. An observation of cooperative post-fledging care in the Torrent Flycatcher is presented. This paper discusses and compares some reproductive components of these New Guinean microecine robins with those of the Jacky Winter and Lemon-bellied Flycatcher.

\section{Study site and methods}

I observed the Olive Flyrobin at my 3-mile banding station at Brown River, near Port Moresby, Papua New Guinea (PNG) $\left(9^{\circ} 18^{\prime} \mathrm{S}, 147^{\circ} 18^{\prime} \mathrm{E}\right)$ during 1968 and 1969 (Filewood 1971). I observed the Papuan Flyrobin and the Torrent 


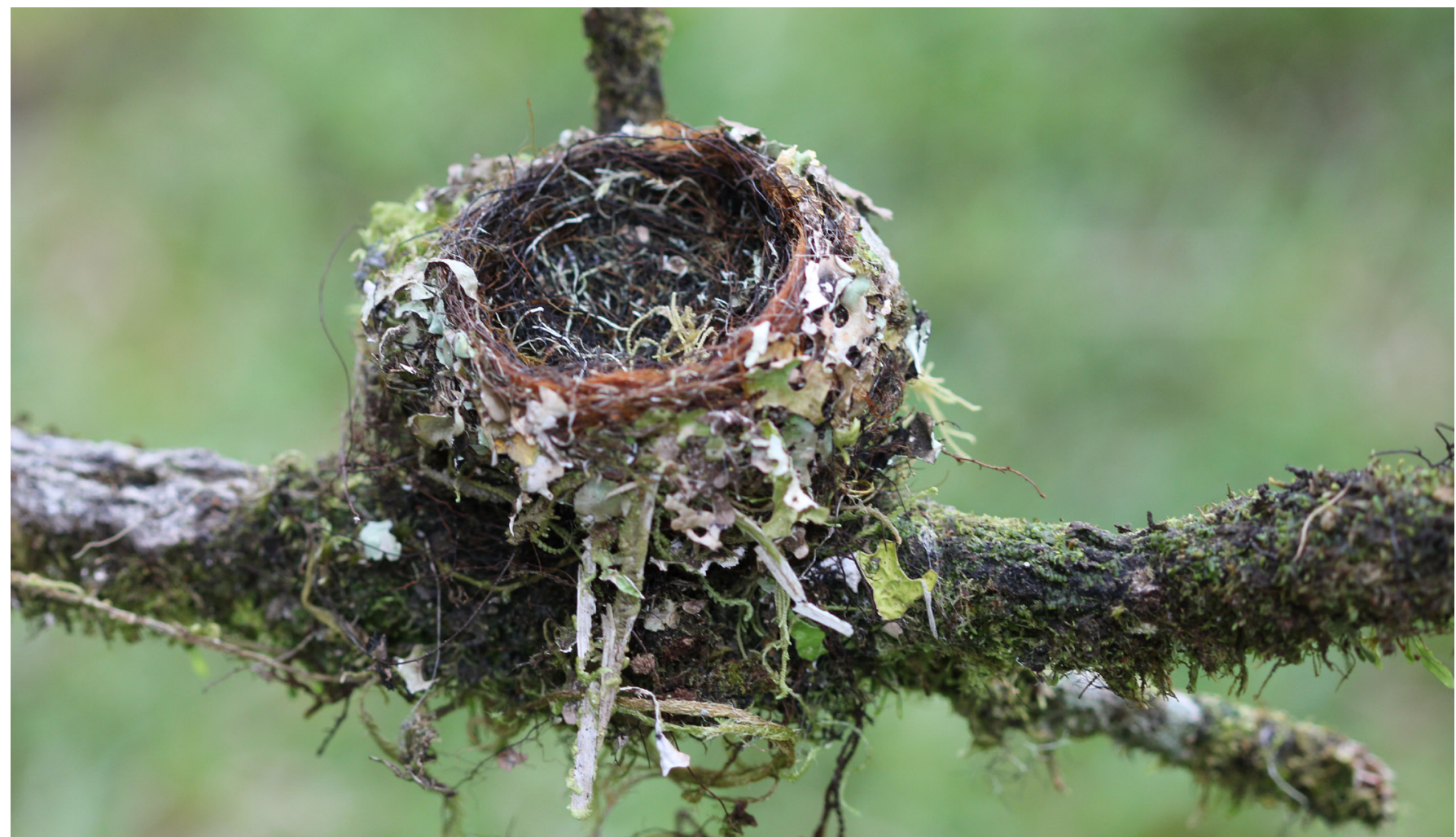

Figure 1. Nest of Papuan Flyrobin in montane rainforest, Mt Hagen, Papua New Guinea. Photo: Richard H. Donaghey

Flycatcher while staying at Kumul Lodge from 2 October to 17 November 2011. In montane rainforest at $2800 \mathrm{~m}$ asl around Kumul Lodge, on the southern slopes of Mt Hagen, PNG $\left(5^{\circ} 26^{\prime} \mathrm{S}, 143^{\circ} 45^{\prime} \mathrm{E}\right)$, the Papuan Flyrobin coexists with the more common White-winged Robin Peneothello sigillata. The vegetation and climate of this study site are described in Donaghey (2015). I constructed a bushhide and observed a nest of a Papuan Flyrobin through a $25 \times$ telescope mounted on a tripod for 7 hours during the first week of incubation to determine incubation constancy. Incubation constancy is the percentage of daylight hours that an incubating bird spends on the nest. Nestattentiveness, defined as the total number of minutes that a bird spends incubating during a defined period, was also measured. All bouts on and off the nest were timed to the nearest second with a lap/split stop-watch and incubation feeding was recorded. Height of the nest above the ground was measured with a bush-pole and tape measure, and nest-site characteristics were recorded after the end of nesting. Observations of Torrent Flycatchers were made in a garden and adjacent stream near Unda village $\left(5^{\circ} 43^{\prime} \mathrm{S}\right.$, $\left.143^{\circ} 56^{\prime} \mathrm{E}\right)$ below Kumul Lodge in the Lai River catchment on 4 November 2011.

\section{Observations of the Papuan Flyrobin}

\section{Construction, site, materials and dimensions of the nest}

At 0800 h on 4 October 2011 along a forest trail at Kumul Lodge, I watched a group of three Papuan Flyrobins foraging $8 \mathrm{~m}$ up in the upper storey. Two of the Flyrobins captured invertebrates from foliage by sally-snatching, then returned to a horizontal perch. On 6 October, I returned to the site and at $1030 \mathrm{~h}$ I saw one of two Flyrobins fly to the dry leaves of a Pandanus palm and gather spider web. It then flew to and perched on a nest with cup and walls complete, and wiped spider web around the external walls. I checked the nest area regularly but did not see any Flyrobin on or near the nest until $0855 \mathrm{~h}$ on 18 October, when one Flyrobin perched motionless for several minutes $8 \mathrm{~m}$ up near the nest-tree then quivered its wings. A second Flyrobin (presumably the male) flew in quickly and fed the bird (probably the female) soliciting food. Feeding of the female by a male is typical breeding behaviour of Australasian robins that I have observed during the prelaying, incubation and nestling periods in $>20$ species. At $0940 \mathrm{~h}$ on 21 October, I first saw a Flyrobin sitting on the nest and then saw the male feed the female on the nest. I assembled a bush hide near the nest on 25 October. Even though the egg and clutch-size for this species are unknown, I decided not to inspect the high and exposed nest so as to reduce human disturbance and the risk of nest-predation.

The exposed nest was situated on a horizontal mossy lateral branch (diameter $18 \mathrm{~mm}$ ) and supported by a small lateral twig (diameter $9 \mathrm{~mm}$ ) (Figure 1). It was placed in the upper foliage $1.5 \mathrm{~m}$ away from the trunk of a tall $(8 \mathrm{~m})$ flowering tree, Saurauia capitulata (Actinidiaceae, Chinese Gooseberry family), $6.6 \mathrm{~m}$ above the ground. The small, neat nest was decorated profusely on the outside with large pieces of filamentous, pale-green lichen and strips of green and brown hanging moss (Figure 1). Its rim was composed of rufous-brown tree-fern fibre, and the interior was lined with fine black rootlets interwoven with whitish aerial rootlets of climbers and/or orchids, 1-2 cm long and $0.5-1.0 \mathrm{~mm}$ in diameter, and some narrow strands of papery lichen and yellow-green moss. The external nest diameter measured $6.3-6.5 \mathrm{~cm}$ and the external depth was $4.0 \mathrm{~cm}$. The internal nest diameter was $4.7 \mathrm{~cm}$ and the internal depth $2.0 \mathrm{~cm}$. 


\section{Incubation rhythm and incubation feeding}

During two 2-h afternoon nest-watches on 26 October 2011, from $1200 \mathrm{~h}$ to $1400 \mathrm{~h}$ and from $1500 \mathrm{~h}$ to $1700 \mathrm{~h}$, in the first week of incubation, female nest-attentiveness and incubation constancy were 51.04 minutes and $42.5 \%$, and 74.98 minutes and $62.5 \%$, respectively. For a 3-h morning nest-watch on 27 October from $0900 \mathrm{~h}$ to $1200 \mathrm{~h}$, nest-attentiveness and incubation constancy were 100.92 minutes and $56.1 \%$, respectively. For the total 420 minutes of observation, female nest-attentiveness and incubation constancy were 226.94 minutes and $54.0 \%$, respectively. The mean incubation constancy per hour was $56.1 \%$ in the morning and $52.5 \%$ in the afternoon (range $41 \%$ from $1200 \mathrm{~h}$ to $1300 \mathrm{~h}$ to $69.8 \%$ from $1500 \mathrm{~h}$ to $1600 \mathrm{~h}$ ). The mean duration of all incubation sessions was 3.80 minutes (range $0.20-12.70$ min., $n=61$ ) and for all absences was 3.11 minutes (range 0.07-8.95 min., $n=62$ ). The mean number of nest visits by the female was 9 per hour or an estimated 108 per 12-h day and the nest visits by the female and male combined was 10.6 per hour. The sitting female uttered peeps, rapidly quivered and elevated her wings, and was fed by a male four times from $1200 \mathrm{~h}$ to $1400 \mathrm{~h}$ and once between $1500 \mathrm{~h}$ and $1700 \mathrm{~h}$. The next morning, the sitting female was fed at the nest by a male four times between $0900 \mathrm{~h}$ and $1200 \mathrm{~h}$, and once the male quickly fed the female as he hovered over her.

\section{Anti-predator behaviour and nest failure}

On 27 October, I entered the hide and no bird visited the nest from $0700 \mathrm{~h}$ to $0800 \mathrm{~h}$. I was unaware of any potential predators present. I assumed that the nest had been depredated, but at $0857 \mathrm{~h}$ a Papuan Flyrobin was sitting on the nest. During a nest-watch on 26 October at $1350 \mathrm{~h}$, the female Flyrobin darted off the nest when a female-plumaged Ribbon-tailed Astrapia Astrapia mayeri (Paradisaeidae) foraged $\sim 40 \mathrm{~m}$ from the nest-tree. The Flyrobin returned to its nest 7 minutes later. At $0905 \mathrm{~h}$ on 30 October, the female Flyrobin swooped off the nest as a female-plumaged Ribbon-tailed Astrapia flew into the nesttree chasing an immature Brown Sicklebill Epimachus meyeri (Paradisaeidae). A Papuan Flyrobin flew into the nest-tree $\sim 1 \mathrm{~m}$ above the nest and fluttered down onto its nest soon after the birds-of-paradise flew off. The Flyrobin was last seen sitting on its nest at $0930 \mathrm{~h}$ on 30 October, but was not on the nest throughout the next morning, as apparently the nest had failed.

\section{Nest and egg of the Olive Flyrobin}

Tony Layton and I (Layton \& Donaghey 1969) observed a Microeca flycatcher with olive upperparts, yellowish underparts, yellow legs and a yellow lower mandible sitting on a nest $6 \mathrm{~m}$ above ground and foraging nearby in lowland rainforest at Brown River, near Port Moresby, PNG, on 3 May 1969, but gave no information on nest materials, dimensions or contents. We misidentified this Microeca robin with yellow legs as a Yellow-legged Flyrobin (formerly Yellow-footed Flycatcher M. griseoceps: see Rand \& Gilliard 1967), since we thought that the Olive Flyrobin had brown feet (Rand \& Gilliard 1967) and were unaware that the Yellow-legged Flyrobin inhabited hill forests. The Olive Flyrobin is the only resident breeding flyrobin recorded at Brown River (Filewood 1971; Bell 1982a), so the nest that we had found was most likely of this species.
The nest was placed $\sim 6 \mathrm{~m}$ above ground on a horizontal branch (diameter $2.5 \mathrm{~cm})$ of a tall $(\sim 30 \mathrm{~m})$ rainforest tree. The open-cup-shaped nest was composed externally of dried leaves and decorated on the outside mainly with pieces of bark 6-19 mm long, coated with cream, green and pale-blue fungus and some lichen, and bound with spider web. The interior of the nest was composed of fine shredded bark, rootlets, grass, moss and small pieces of lichen. Externally the nest measured $4.5-4.8 \mathrm{~cm}$ in diameter and it was $2.7 \mathrm{~cm}$ deep. The mean internal nest diameter was $3.3 \mathrm{~cm}$ and the internal depth was $1.9 \mathrm{~cm}$. The single egg was pale green with light-brown, darkbrown and lavender-grey blotches concentrated on the larger end.

\section{Observations of the Torrent Flycatcher}

Below I describe the social behaviour and cooperative post-fledging care in a group of Torrent Flycatchers in the western highlands of PNG.

\section{Group size and composition}

A group of five Torrent Flycatchers was observed on 4 November 2011 along and beside a stream at Unda village $(2100 \mathrm{~m}$ asl), the uppermost elevation known for this species (Beehler \& Pratt 2016). The group consisted of two adults (with black crown, wings and tail), one bird (hereafter called an immature) like the adults but with dark sooty-brown crown, wings and tail, and two juveniles. The juveniles had the crown and nape mid brown, marked with large off-white spots merging into a whitish forehead and blackish ear-patch. Their underparts were white with lightbrown mottling on the mid-upper breast, and the wings were dull brown with pale-brown tips to the greater and lesser wing-coverts.

\section{Habitat and foraging behaviour}

The habitat used by all five birds included a fast-flowing stream (12 $\mathrm{m}$ wide) with many large protruding boulders up to $2 \mathrm{~m}$ high and 2-3 $\mathrm{m}$ wide and many smaller boulders. The stream was fringed by dense forest on one side and a food garden with mostly Sweet Potato Ipomoea batatas and fringing tall trees such as Casuarina and Breadfruit Artocarpus altilis on the other side. The Torrent Flycatchers perched motionless on the top of stream boulders and on 1-2-m-high garden sticks, but often 5-6 $\mathrm{m}$ up on branches and 3-5 m up on short lateral stubs of branches in Casuarina trees. Foraging behaviour consisted mostly of aerially flycatching (hawking) from a Casuarina perch and often returning to the same branch, but also by sally-snatching at the foliage, branches and trunks of Casuarina and broadleaved trees overhanging the stream. Sometimes the birds gleaned from rocks, banks and tree-trunks and pounced to the ground from a low perch.

\section{Social behaviour and interspecific interactions}

The two juvenile Torrent Flycatchers perched close together on inner branches of Casuarina trees and on stream boulders. Both adults fed the juvenile birds, which quivered their wings and held them slightly out from the body while begging for food. The immature bird sometimes perched with the two juveniles and twice fed one of them. Once, the two adult and immature Torrent Flycatchers 
chased a Willie Wagtail Rhipidura leucophrys back and forth along the stream and over the gardens.

\section{Discussion}

\section{Breeding system}

In this study, a group of three Papuan Flyrobins foraged together during the nest-building phase, but only two birds were observed together at the nest during incubation. Pairs of Papuan Flyrobins were observed at two different sites, and once I observed a second group of three adult Papuan Flyrobins foraging together $4-6 \mathrm{~m}$ up in the forest understorey, and capturing prey by sally-snatching from foliage and gleaning from mossy trunks. Coates (1990) reported groups of up to four birds, thus pair-breeding and cooperative feeding of young might occur. Facultative cooperative breeding and pair-breeding occurs in the Jacky Winter (Donaghey in Higgins \& Peter 2002) and Lemonbellied Flycatcher (Noske 2011). Further study is required to determine if small groups of Torrent Flycatchers engage in cooperative breeding. The Olive Flyrobin appears to be a territorial pair-breeder (Bell 1982b; Coates 1990).

\section{Breeding season}

My observations of a Papuan Flyrobin nest-building and incubating in October (this paper) and observations of dependent fledglings in February, a bird sitting on a nest in early April and birds in breeding condition in December (Coates 1990) suggest a breeding season for the Papuan Flyrobin of up to 7 months, from October to April.

\section{Nest, nest-site, egg, and clutch-size}

The two Microeca species that occur in more open habitats, the Jacky Winter and Lemon-bellied Flycatcher, are similar in body size, and in their use of nest materials and nest placement (Higgins \& Peter 2002). The nests of the three New Guinean rainforest flyrobins are more profusely decorated with lichen, moss and bark pieces that match the nest-support branches, and are built in the mid-upper levels of the forest (Noske \& Sticklen 1979; this study, Figure 1). Two of these flyrobin species, the Olive Flyrobin and Papuan Flyrobin, build more exposed nests at greater heights than those of coexisting montane robins of the genera Heteromyias, Peneothello, Pachycephalopsis and Amalocichla, which build bulkier nests in the lower understorey (Coates 1990; RHD pers. obs.).

New Guinean forest passerines lay much smaller clutches (mean 1.5 eggs) than related tropical passerines of south-eastern Asia (Freeman \& Mason 2014). Among New Guinean robins (Petroicidae) for which clutch-size is known, montane species have a one-egg clutch and truly lowland species have a clutch-size of two or one, although for many lowland species the clutch-size is undescribed (Donaghey 2015). Three rainforest robins (White-faced Robin Tregellasia leucops, Yellow-legged Flyrobin, and Northern Scrub-robin Drymodes superciliaris) of lowland Cape York Peninsula, Australia, have a clutch-size of two (Coates 1990; Higgins \& Peter 2002). In New Guinea, the first two species and the Papuan Scrub-robin $D$. beccarii (Beehler \& Pratt 2016; Gill \& Donsker 2017) occur in foothills and lower montane forests. Clutch-size is one or two in the White-faced Robin and unknown in the latter two species (Pratt \& Beehler 2015). The clutch-size of the Papuan Flyrobin is unknown, but at least two fledglings have been observed with adults (Coates 1990).

\section{Incubation behaviour}

Diurnal incubation constancy was $54 \%$ in the Papuan Flyrobin in montane tropical New Guinea (this study), $69 \%$ in the Jacky Winter in semi-arid southern Australia (Donaghey \& Donaghey 2017) and $~ 30 \%$ in the Lemonbellied Flycatcher in tropical northern Australia (Noske 2011). This variation in flyrobin incubation constancy can be explained largely by differences in ambient temperature. Noske (2011) also reported that incubation constancy was $67 \%$ for 14 Australian insectivorous passerines and $75 \%$ for 95 North American passerines. For the female Papuan Flyrobin, the mean number of incubation sessions was 9 per hour and an estimated 108 for a 12-hr day. A similar number of sessions per hour was recorded for the Jacky Winter (Donaghey \& Donaghey 2017), but the mean length of Papuan Flyrobin sessions (3.8 min.) was slightly shorter than for the Jacky Winter. Conway \& Martin (2000) measured mean nest trips per hour as the number of times that the incubating female went to and from the nest per hour. By this calculation, the incubating Papuan Flyrobin went to and from the nest 18 times per hour, five times higher than the mean trips per hour of 3.6 (range 1-15) for 95 species of northern temperate passerines in which only the female incubates (Conway \& Martin 2000). High rates of egg-predation might select for high nest-attentiveness, short off-bouts and fewer nest visits so as to reduce activity of the adults at the nest, but this strategy places constraints on how females allocate time for foraging (Conway \& Martin 2000). Incubating female Papuan Flyrobins had lower nest-attentiveness, much shorter and more frequent on- and off-bouts and more nest visits relative to northern temperate passerines (Conway \& Martin 2000; Higgins \& Peter 2002; this study). Presumably, high nest visitation and short on- and off-bouts have evolved to meet the female's energy needs.

\section{Nest failure and risk of predation}

The Papuan Flyrobin nest failed during the incubation stage but the cause of failure was unknown. Nestling mortality is the primary cause of reproductive failure in Australian songbirds (Ford et al. 2001; Remeš et al. 2012). High nest-predation is characteristic of open-cup-nesting passerines of Australian forests and woodlands and accounts for $50-60 \%$ of nest failure (Ford et al. 2001). In Australia, nest-predation varies regionally, and increases from temperate regions to the northern tropics (Remeš et al. 2012). Nest failure rate is unknown for nearly all New Guinean passerines. However, for New Guinean Microeca species that occur in Australia, the Jacky Winter nest failure was $77.8 \%$ at Gluepot Reserve, South Australia (Donaghey \& Donaghey 2017), and $75 \%$ in south-eastern Queensland (Wood et al. 2008). In the Lemon-bellied Flycatcher, the nest-predation rate was $56 \%$ around Darwin, Northern Territory (Noske 2011). The Papuan Flyrobin, Lemon-bellied Flycatcher and Jacky Winter avoid large avian potential predators by darting off the nest and not returning until the predator has departed (Noske 2011; Donaghey \& Donaghey 2017; this study). Based on the responses of small passerines to larger birds, potential avian predators of flyrobin nest contents include goshawks 
(Accipitridae), kookaburras (Alcedinidae), bowerbirds (Ptilonorhynchidae), Melidectes honeyeaters and friarbirds (Meliphagidae), butcherbirds and currawongs (Artamidae), Australian shrike-thrushes and New Guinean shrikethrushes (formerly called pitohuis) (Pachycephalidae), birds-of-paradise, and corvids (Corvidae) (Higgins \& Peter 2002; Wood et al. 2008; Donaghey 2017; RHD pers. obs.). Papuan and Olive Flyrobins, Lemon-bellied Flycatchers and Jacky Winters build small nests and have small clutchsizes, and nestling Jacky Winters and Lemon-bellied Flycatchers have mottled, cryptic plumage and adopt anti-predator postures (Harvey \& Harvey 1919; Higgins \& Peter 2002; Noske 2011; Donaghey \& Donaghey 2017), suggesting that these traits have evolved in response to a high risk of nest-predation.

\section{Acknowledgements}

The late lan Burrows first suggested I study robins at Kumul Lodge. I thank Josephine and all the staff at Kumul Lodge, especially Max Mal for helping me retrieve the failed nest of the Papuan Flyrobin, and horticulturalists Steve Hootman and Bob Cherry for helping me identify the nest-tree of the Papuan Flyrobin. My late mother Mrs E. Donaghey financed my robin research in Papua New Guinea. Sue Gregory supplied the coordinates for Kumul Lodge. Peter Stronach helped me obtain coordinates for Unda village from Google Earth. Darryl Jones endorsed my position at Griffith University, and the Griffith University Library provided internet access to journals. My research in New Guinea is inspired by the pioneering research on avian life histories by Cliff and Dawn Frith in montane forests at Tari Gap, Southern Highlands, PNG, and the splendid books on birds of New Guinea by Brian Coates, Bruce Beehler and Thane Pratt. I thank the reviewers, Bruce Beehler, Walter Boles and Richard Noske, and editors James Fitzsimons and Cliff Frith, for their comments, which greatly improved this paper.

\section{References}

Beehler, B.M. \& Pratt, T.K. (2016). Birds of New Guinea: Distribution, Taxonomy, and Systematics. Princeton University Press, Princeton, New Jersey, USA.

Bell, H.L. (1982a). A bird community of lowland rainforest in New Guinea. 1. Composition and density of the avifauna. Emu 82, 24-41.

Bell, H.L. (1982b). A bird community of lowland rain forest in New Guinea. 2. Seasonality. Emu 82, 65-74.

Boles, W.E. (2007). Family Petroicidae (Australasian robins). In: del Hoyo, J., Elliot, A. \& Christie, D.A. (Eds). Handbook of the Birds of the World, Volume 12: Picathartes to Tits and Chickadees, pp. 438-488. Lynx Edicions, Barcelona, Spain.

Christidis, L. \& Boles, W.E. (2008). Systematics and Taxonomy of Australian Birds. CSIRO Publishing, Melbourne.

Christidis, L., Irestedt, M., Rowe, D., Boles, W.E. \& Norman, J.A. (2011). Mitochondrial and nuclear DNA phylogenies reveal a complex evolutionary history in the Australasian robins (Passeriformes: Petroicidae). Molecular Phylogenetics and Evolution 61, 726-738.
Coates, B.J. (1990). The Birds of Papua New Guinea, Volume II: Passerines. Dove Publications, Brisbane.

Conway, C.J. \& Martin, T.E. (2000). Evolution of passerine incubation behavior: Influence of food, temperature, and nest predation. Evolution 54, 670-685.

Croxall, J.P. (1977). Feeding behaviour and ecology of New Guinea rainforest insectivorous passerines. Ibis 119, $113-146$.

Diamond, J.M. (1972). Avifauna of the Eastern Highlands of New Guinea. Publications of the Nuttall Ornithological Club, No. 12. Cambridge, Massachusetts, USA.

Donaghey, R.H. (2015). Nest and egg of the Dimorphic Fantail Rhipidura brachyrhyncha and a review of clutch-sizes in New Guinean passerines. Australian Field Ornithology 32, 69-86.

Donaghey, R.H. (2017). Incubation behaviour and care of a nestling by a pair of Black Fantails Rhipidura atra. Australian Field Ornithology 34, 56-58.

Donaghey, R.H. \& Donaghey, C.A. (2017). Parental care and breeding strategies of the Jacky Winter and its life-history traits compared with other Australasian robins, and northern temperate and tropical songbirds. Australian Field Ornithology 34, 98-110.

Dutson, G. (2011). Birds of Melanesia: The Bismarcks, Solomons, Vanuatu and New Caledonia. Christopher Helm, London.

Filewood, L.W. (1971). A New Guinea jungle banding station. Australian Bird Bander 9, 1-7.

Ford, H.A., Barrett, G.W., Saunders, D.A. \& Recher, H.F. (2001). Why have birds in the woodlands of southern Australia declined? Biological Conservation 97, 71-88.

Freeman, B.G. \& Mason, N.A. (2014). New Guinean passerines have globally small clutch-sizes. Emu 114, 304-308.

Gill, F. \& Donsker, D. (Eds) (2017). IOC World Bird List (v. 7.1). Available online: http://www.worldbirdnames.org (retrieved 28 January 2017).

Harvey, W.G. \& Harvey, R.C. (1919). Bird notes from Mackay, Q. Emu 19, 34-42.

Higgins, P.J. \& Peter, J.M. (Eds) (2002). Handbook of Australian, New Zealand \& Antarctic Birds, Volume 6: Pardalotes to Shrike-thrushes. Oxford University Press, Melbourne.

Layton A. \& Donaghey, R. (1969). Observations (Brown River). New Guinea Bird Society Newsletter 42, 1.

Noske, R. (2011). Lemon-essence. Wingspan 21 (4), 36-39.

Noske, R.A. \& Sticklen, R. (1979). Nest and eggs of the Yellowlegged Flycatcher. Emu 79, 148-149.

Pratt, T.K. \& Beehler, B.M. (2015). Birds of New Guinea. 2nd edn. Princeton University Press, Princeton, New Jersey, USA.

Rand, A.L. \& Gilliard, E.T. (1967). Handbook of New Guinea Birds. Weidenfeld \& Nicolson, London.

Remeš, V., Matysioková, B. \& Cockburn, A. (2012). Long-term and large-scale analyses of nest predation patterns in Australian songbirds and a global comparison of nest predation rates. Journal of Avian Biology 43, 435-444.

Wood, K.A., Thompson, N. \& Ley, A.J. (2008). Breeding territories and breeding success of the Jacky Winter Microeca fascinans in south-eastern Queensland. Australian Field Ornithology 25, 121-131.

Received 1 February 2017, accepted 9 July 2017, published online 4 October 2017 